\title{
Pelevelan Model Mental Siswa Dalam Memahami Konsep Persamaan Garis Lurus Di Era Pandemi COVID-19
}

\author{
Rizkia Nur Laili, Anita Dewi Utami, Nur Rohman
}

How to cite : Laili, R.N, Utami, A. D., \& Rohman, N. (2021). Pelevelan Model Mental Siswa Dalam Memahami Konsep Persamaan Garis Lurus Di Era Pandemi COVID-19. Kognitif: Jurnal Riset HOTS Pendidikan Matematika, 1(2), 89 - 103. https://doi.org/10.51574/kognitif.v1i2.86

To link to this article : https://doi.org/10.51574/kognitif.v1i2.86

Opened Access Article

曲 Published Online on 1 Juni 2021

至 


\title{
Pelevelan Model Mental Siswa Dalam Memahami Konsep Persamaan Garis Lurus Di Era Pandemi COVID-19
}

\author{
Rizkia Nur Laili ${ }^{1}$, Nur Rohman ${ }^{2}$, Anita Dewi Utami ${ }^{3 *}$ \\ 1,2,3 Program Studi Pendidikan Matematika, IKIP PGRI Bojonegoro
}

\begin{tabular}{l} 
Article Info \\
\hline Article history: \\
Received Aug 16, 2021 \\
Accepted Sept 13, 2021 \\
Published Online Dec 1, 2021 \\
\hline
\end{tabular}

Keywords:

Pelevelan

Model Mental

Persamaan Garis Lurus

\begin{abstract}
Pelevelan model mental merupakan salah satu cara untuk melihat sejauh mana pemahaman siswa yang didasarkan pada tingkatan masing-masing level. Menurut pendapat para ahli tidak dapat dikesampingkan bahwa level pemahaman masing-masing siswa tentunya berbeda-beda, mulai dari tingkatan rendah, menengah, hingga tingkat atas dan pelevelan pemahaman siswa itu sendiri dapat diukur dengan berbagai hal, salah satunya adalah model mental. Model mental bisa digunakan untuk mengetahui tingkat pemahaman siswa dan menunjukkan cara berpikir siswa. Tujuan penelitian ini adalah untuk mendeskripsikan enam level model mental siswa kelas VIII dalam memahami konsep persamaan garis lurus. Metode yang digunakan peneliti dalam penelitian ini adalah metode penelitian kualitatif. Subjek dalam penelitian ini adalah siswa kelas VIII dengan jumlah 121 siswa, subjek tersebut diambil agar terpenuhi masingmasing level model mental. Kemudian diambil 2 siswa untuk diwawancarai sebagai subjek terpilih yang menjadi perwakilan masing-masing level model mental. Sehingga diperoleh 12 siswa sebagai subjek wawancara. Instrumen dalam penelitian ini meliputi soal tes dan pedoman wawancara yang sebelumnya divallidasi. Prosedur pengumpulan data yaitu dengan observasi, tes, wawancara, serta dokumentasi. Peneliti menganalisis data dengan dua cara, yaitu triangulasi sumber data dan triangulasi metode untuk memastikan kevalidan data. Sehingga diperoleh hasil penelitian yang menunjukkan deskripsi masing-masing level model mental siswa dalam memahami konsep persamaan garis lurus.
\end{abstract}

This is an open access under the CC-BY-SA licence

All rights reserved.

\section{Corresponding Author:}

Anita Dewi Utami,

Pendidikan Matematika,

Fakultas Keguruan dan Ilmu Pendidikan,

IKIP PGRI Bojonegoro,

Jl. Panglima Polim No. 46, Pacul, Kec. Bojonegoro, Jawa Timur

ID Scopus: 57204109939

Email: anitadewiutami28@gmail.com

\section{Pendahuluan}

Pelajaran matematika membutuhkan ketekunan serta keuletan, sehingga kebanyakan dari siswa menganggap matematika adalah pelajaran yang membosankan dan rumit, bahkan 
menakutkan. Sesuai dengan pendapat Mulyono Abdurrahman dalam Sholekah (2017: 152) bahwa dari berbagai bidang studi yang dipelajari di sekolah, matematika merupakan bidang studi yang paling sulit dipelajari oleh siswa, baik yang tidak merasa kesulitan belajar, maupun bagi siswa yang kesulitan dalam belajar. Maka sebagian siswa cenderung menghafal materi pelajaran matematika hanya untuk memenuhi syarat ujian saja yang berakibat sering ditemukan kekeliruan dalam pemahaman konsep.

Konsep adalah salah satu aspek yang terkandung dalam pembelajaran matematika. Sesuai dengan penelitian Dahar dalam Murizal (2012) bahwa konsep-konsep diibaratkan seperti sekumpulan batu-batu pembangunan dalam berpikir. Hardiyanti, dkk., (2012) menyatakan bahwa pemahaman konsep dalam pembelajaran matematika merupakan hal yang penting supaya siswa tidak mengalami kesulitan dalam belajar. Memahami konsep matematika juga akan memudahkan siswa dalam memecahkan suatu masalah matematika. Hal tersebut menunjukkan bahwa pemahaman konsep merupakan suatu hal yang penting dan harus dimiliki oleh siswa.

Menurut pendapat para ahli di atas, tidak dapat dikesampingkan bahwa level pemahaman masing-masing siswa tentunya berbeda-beda, mulai dari tingkatan rendah, menengah, hingga tingkat atas. Pelevelan merupakan tingkatan kemampuan yang dicapai, dimana semakin tinggi kemampuan seseorang maka akan semakin tinggi pula level yang dicapai. Pelevelan pemahaman siswa dapat diukur dengan berbagai hal, salah satunya adalah model mental. Kegiatan mental dapat dilihat dari pemahaman suatu konsep pada pembelajaran matematika (Rachmawati, 2019). Mental terdiri dari berbagai model, sebagaimana banyaknya model-model mental. Pengertian model sesuai Kamus Besar Bahasa Indonesia yaitu pola (contoh, acuan, ragam, dan sebagainya) dari sesuatu yang akan dibuat atau dihasilkan. Sedangkan mental adalah segala hal yang kaitannya dengan batin atau watak manusia, yang bukan bersifat badan atau tenaga dimana yang menjadi perhatian bukan hanya pembangunan fisik melainkan pembangunan. Sesuai dengan pendapat Sange (2004) bahwa model mental merupakan gambaran internal serta gambaran yang membatasi seseorang dalam bertindak. Model mental dianggap mewakili ide-ide dalam pikiran sesorang dalam menggambarkan dan menjelaskan suatu kejadian (Jansoon, et al., 2009). Sedangkan menurut Rachmawati (2019) model mental bisa digunakan untuk mengetahui tingkat pemahaman siswa. Utami (2018) juga berpendapat bahwa model mental dapat digunakan untuk menunjukkan cara berpikir siswa.

Penelitian model mental ditemukan dalam berbagai kajian, salah satunya kajian psikologi kognitif. Psikologi kognitif adalah cabang psikologi yang mempelajari tentang proses mental termasuk diantaranya bagaimana orang berpikir, merasakan, mengingat, dan belajar. Penelitian model mental juga terdapat dalam kajian science. salah satunya menurut Lehrer $\underline{\text { (2009) }}$ belajar sains (khususnya fisika) adalah untuk mengkonstruksi, merevisi, serta melakukan justifikasi model mental yang dibangun sendiri, tidak hanya mengadaptasi model dari orang lain dan diterima begitu saja. Tujuan utama pembelajaran fisika yakni untuk membantu siswa membangun model mental secara ilmiah dengan pengajaran yang sesuai. Sehingga yang menjadi prioritas yaitu menyelidiki model mental dari masing-masing siswa serta diajarkan sesuai yang disarankan oleh para konstruktivis.

Selain telah banyak ditemukannya penelitian model mental pada beberapa kajian, Penelitian model mental telah banyak diteliti oleh banyak peneliti terdahulu, sehingga terbagi beberapa pelevelan model mental. Kemudian Vasniadou (1992) membagi model mental menjadi tiga yakni model mental inisial, sintetis, dan formal. Sementara itu, Park \& Light (2009) melevelkan model mental menjadi lima kategori, antara lain model mental awal tak berbentuk, model mental intermediate 1 , model mental intermediate 2 , model mental intermediate 3 dan model mental target. 
Sedangkan dalam penelitian science terutama pada matematika hanya terdapat beberapa penelitian model mental. Diantaranya penelitian model mental oleh Bofferding (2014) yang melevelkan model mental menjadi lima model terhadap pemahaman konsep bilangan bulat. Antara lain model mental inisial, transisi I, model mental sintetik, transisi II, dan model mental formal. Kemudian dari penelitian tersebut dikembangkan oleh Utami (2018: 4) menjadi enam pelevelan model mental yaitu terdapat model mental pra-inisial sebelum model mental inisial, sehingga dari hasil penelitian tersebut menunjukkan bahwa pelevelan model mental siswa ada enam, diantaranya model mental pra-inisial, model mental inisial, model mental transisi I, model mental sintesis, model mental transisi II, dan model mental formal.

Pemahaman konsep persamaan garis lurus merupakan salah satu topik menarik yang dapat dikaji pada pelevelan model mental siswa. Hal tersebut dikarenakan persamaan garis lurus merupakan konsep awal dimana siswa dapat mengembangkan konsep fungsi yang telah dipelajari sebelumnya. Meskipun persamaan garis lurus bukan termasuk materi yang sangat sulit, akan tetapi capaian yang diperoleh siswa khususnya dalam ujian nasional belum memuaskan (Retnawati, 2017). Menurut Tanjungsari et al (2012) pemahaman konsep persamaan garis lurus siswa masih kurang, dilihat dari beberapa masalah, salah satunya siswa masih merasa kesulitan dalam menggunakan konsep termasuk didalamnya ketidakmampuan untuk mengingat konsep, ketidakmampuan mendeduksi informasi berguna dari suatu konsep dan kurangnya kemampuan memahami (schematic knowledge) yang ditunjukkan dengan kurang lengkap dalam menuliskan rumus. Menurut hasil penelitian Hardiyanti (2012) kesalahan pemahaman konsep pada topik persamaan garis lurus: (a) Tipe: hasil kali gradien dari dua garis yang sejajar adalah -1 serta gradien dari dua garis yang saling tegak lurus hasil kalinya adalah 1. (b) Kecenderungan: kesalahan dalam menentukan persamaan garis lurus yang melalui dua titik, melalui suatu titik dan sejajar dengan suatu garis maupun tegak lurus dengan suatu garis, dan dalam menentukan gradien garis dengan persamaan

$$
y=m x+c
$$

Berdasarkan wawancara yang dilakukan terhadap guru matematika di salah satu sekolah menengah pertama di Bojonegoro terkait pemahaman konsep siswa pada materi persamaan garis lurus menunjukkan bahwa siswa kesulitan mengaplikasikan rumus gradien dan persamaan garis lurus yang tepat pada suatu soal yang telah diberikan oleh guru karena terlalu banyak rumus, siswa sulit menguasai materi persamaan garis lurus dikarenakan materi tersebut ada kaitannya dengan materi sebelumnya yakni aljabar, bidang kartesius, serta grafik yang sebelumnya belum dikuasai. Dari pernyataan tersebut dapat disimpulkan bahwa pemahaman konsep siswa pada materi persamaan garis lurus masih rendah jika dilihat dari indikator pemahaman konsep.

Berdasarkan dari hasil penelitian di atas, perlu diadakan penelitian lebih lanjut terkait hal tersebut untuk mengetahui pelevelan model mental siswa dalam memahami konsep persamaan garis lurus. Oleh karena itu penelitian mengenai pelevelan model mental siswa dalam memahami konsep persamaan garis lurus merupakan hal yang penting untuk dikaji lebih dalam.

Sesuai dengan kebijakan pemerintah Indonesia melalui Kementerian Pendidikan dan Kebudayaan, mengeluarkan Surat Edaran Kementerian Pendidikan dan Kebudayaan (Kemendikbud) No. 4 Tahun 2020 terkait pelaksanaan kebijakan pendidikan pada masa darurat penyebaran Corona Virus Desease (Covid-19) yang terhitung mulai tanggal 24 Maret 2020. Sehingga dengan adanya kebijakan tersebut, sistem pembelajaran telah dirancang sedemikian rupa untuk mencegah terjadinya penyebaran wabah Covid-19. Hal tersebut menyebabkan peneliti berinisiatif melakukan penelitian kualitatif dengan judul "Pelevelan Model Mental Siswa Dalam Memahami Konsep Persamaan Garis Lurus di Era Pandemi Covid-19” dengan alasan penelitian tersebut dapat dilakukan karena yang menjadi subjek penelitian adalah peserta didik yang jumlahnya tidak banyak, tempat dan lokasi juga mudah diakses oleh peneliti dan 
subjek penelitian sesuai dengan protokol kesehatan, serta tidak menggunakan model maupun media pembelajaran secara daring (dalam jaringan) melainkan fokus terhadap analisis level model mental siswa dalam memahami konsep persamaan garis lurus.

Sehingga tujuan penelitian ini untuk mendeskripsikan enam level model mental siswa kelas VIII SMP Plus Al-Amanah dalam memahami konsep persamaan garis lurus. Sehingga dengan adanya penelitian tersebut dapat diketahui dan dikelompokkan level model mental siswa dalam memahami konsep persamaan garis lurus.

\section{Metode}

Penelitian ini merupakan jenis penelitian kualitatif, yaitu penelitian yang bersifat deskriptif dan cenderung menggunakan analisis. Sehingga dengan penelitian kualitatif tersebut dapat diketahui dan dikelompokkan level model mental siswa dalam memahami konsep persamaan garis lurus.

Subyek penelitian dalam penelitian ini berjumlah 121 siswa kelas VIII. Alasan pemilihan subjek tersebut agar terpenuhi keseluruhan model mental. Kemudian dari 121 siswa tersebut akan diambil kembali 12 siswa yang memenuhi standar kriteria pelevelan model mental dan mempunyai kemampuan komunikasi yang baik dan aktif. Adapun indikator yang diambil adalah seperti yang ditunjukkan oleh Tabel 1 .

Tabel 1. Indikator Enam Level Model Mental Dalam Memahami Konsep Persamaan Garis Lurus Adopsi Dari Utami, A. D (2018)

\begin{tabular}{ll}
\multicolumn{1}{c}{$\begin{array}{c}\text { Model } \\
\text { Mental }\end{array}$} & \multicolumn{1}{c}{ Indikator } \\
\hline Pra-Inisial & $\begin{array}{l}\text { Siswa sudah memahami pengertian Sistem Persamaan Linear Satu Variabel, tetapi belum } \\
\text { memahami Persamaan Garis Lurus }\end{array}$ \\
\hline Inisial & $\begin{array}{l}\text { Siswa sudah memahami rumus Persamaan Garis Lurus sesuai titik yang dilalui serta } \\
\text { gradien }\end{array}$ \\
\hline Transisi I & $\begin{array}{l}\text { Siswa sudah memahami persoalan pemecahan masalah yang berkaitan dengan konsep } \\
\text { Persamaan Garis Lurus, tetapi belum konsisten dalam pengerjaannya }\end{array}$ \\
\hline Sintesis & Siswa sudah mampu mengaplikasikan rumus Persamaan garis Lurus dengan benar \\
\hline Transisi II & $\begin{array}{l}\text { Siswa belum konsisten dalam memecahkan masalah yang berkaitan dengan konsep } \\
\text { Persamaan Garis Lurus }\end{array}$ \\
\hline Formal & $\begin{array}{l}\text { Siswa sudah mampu memahami dan konsisten dalan memecahkan masalah yang berkaitan } \\
\text { dengan konsep Persamaan Garis Lurus }\end{array}$ \\
\hline
\end{tabular}

Berdasarkan jawaban 61 siswa yang telah dikelompokkan dalam enam level model mental seperti dalam indikator tabel 1 di atas, berikut distribusi jumlah jawaban siswa yang ditunjukkan Tabel 2.

Tabel 2 Jumlah Siswa Pada Masing - masing Level Model Mental

\begin{tabular}{lll}
\hline No. & Model Mental & Jumlah Siswa \\
\hline 1. & Pra-Inisial & 8 siswa \\
\hline 2. & Inisial & 16 siswa \\
\hline 3. & Transisi I & 21 siswa \\
\hline 4. & Sintesis & 35 siswa \\
\hline 5. & Transisi II & 22 siswa \\
\hline 6. & Formal & 19 siswa \\
\hline
\end{tabular}


Berdasarkan jumlah siswa pada masing - masing level yang ditunjukkan oleh tabel 2, dipilih dua orang untuk diwawancarai. Pemilihan subjek untuk diwawancarai didasarkan pada kemampuan komunikasi siswa.

Instrumen pada penelitian ini adalah soal tes dan pedoman wawancara. Soal tes terdiri dari 6 butir soal dengan masing-masing soal memiliki tingkatan sesuai dengan level model mental. Prosedur pengumpulan data yang digunakan dalam penelitian ini yaitu observasi untuk memilih beberapa siswa yang nantinya akan dikelompokkan sesuai dengan level model mental. Tes diberikan kepada siswa kelas VIII secara luring (offline) yang sebelumnya divalidasi. Langkah terakhir yaitu wawancara dengan 12 siswa yang terpilih. Kemudian dilakukan wawancara dengan 12 siswa yang telah dipilih dan memenuhi masing-masing level model mental menggunakan pedoman wawancara tak terstruktur serta menggunakan aplikasi WhatsApp. Selain menggunakan teknis pengumpulan data yang berupa observasi, tes, wawancara, peneliti juga menggunakan dokumentasi untuk melengkapi data. Dokumentasi yang digunakan adalah berupa catatan dan screenshot hasil wawancara serta dokumentasi berupa foto atau gambar pada saat pelaksanaan tes.

Analisis data dilakukan setelah memperoleh data hasil penelitian yaitu melakukan tes dan wawancara. Sebelum melakukan tes, peneliti telah melakukan observasi untuk mengamati sejauh mana pengetahuan yang telah dimiliki siswa. Kemudian melakukan tes dimana sebelumnya peneliti telah menyiapkan soal dan melakukan validasi soal dan pedoman wawancara yang akan diberikan kepada siswa. Setelah hasil tes diperoleh, peneliti menimbang dan memilih 12 subjek terpilih untuk dilakukan wawancara. Wawancara dilakukan melalui aplikasi WhatsApp dan screenshot hasil wawancara yang telah terkumpul kemudian dianalisis dengan cermat dengan memperhatikan hubungan antara hasil tes dan hasil wawancara. Sehingga peneliti berhasil menemukan data dalam pengelompokan enam level model mental terkait pemahaman konsep persamaan garis lurus.

\section{Hasil Penelitian}

Berikut adalah hasil analisis pada enam level model mental dengan subjek penelitian dalam memahami konsep persamaan garis lurus.

\section{Level Model Mental Pra-Inisial}

Subjek ADS tidak dapat menjawab soal tes dengan benar. Jawaban subjek ADS mengatakan bahwa dalam mengklasifikasikan objek siswa masih kurang paham tentang bentuk persamaan garis lurus. Berikut jawaban dari subjek ADS:.

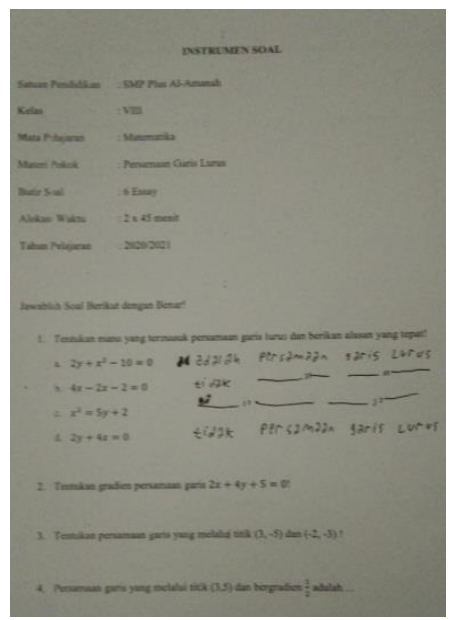


Gambar 1. Model Mental Pra-Inisial Subjek ADS

Berdasarkan jawaban di atas, menunjukkan bahwa subjek ADS belum memahami bentuk persamaan garis lurus. Terlihat dari screenshot hasil wawancara dengan subjek ADS yaitu:
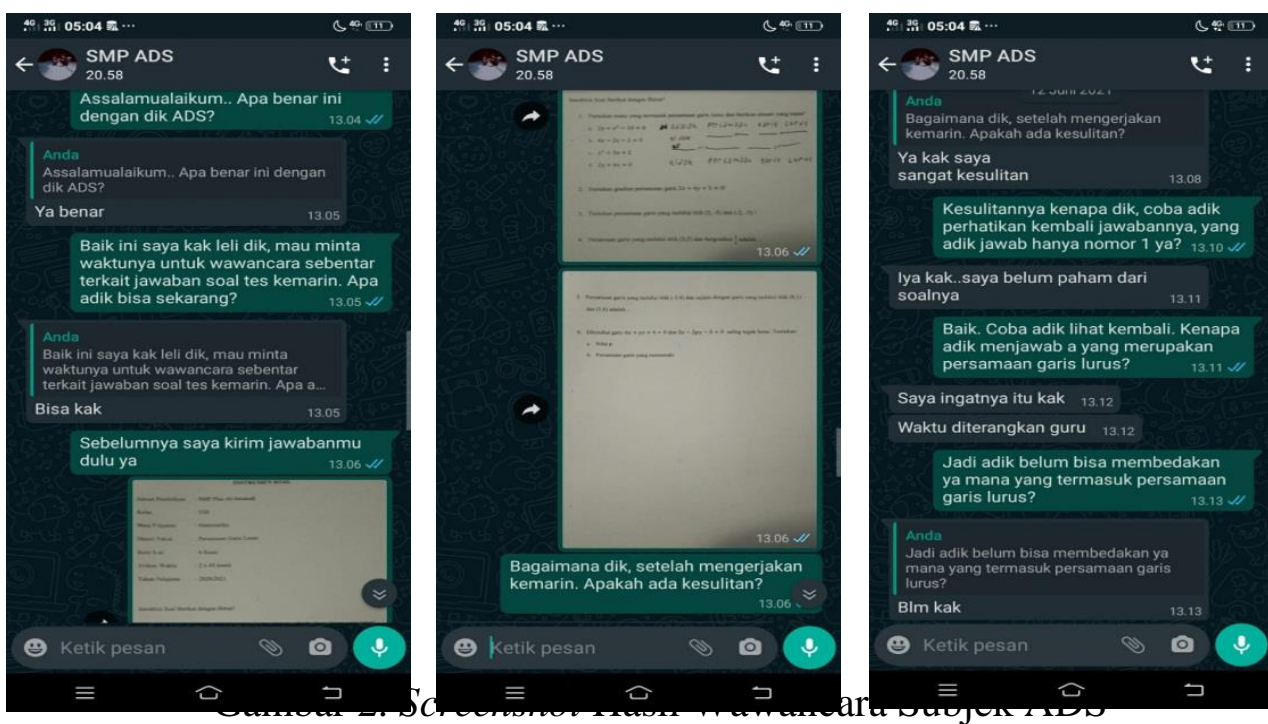

Berdasarkan hasil jawaban dan wawancara di atas dapt disimpulkan bahwa subjek ADS belum memahami sama sekali terkait konsep persamaan garis lurus, sehingga termasuk dalam level pra inisial.

Selain subjek ADS juga terdapat subjek NS yang memiliki kesalahan yang sama. Sehingga level model mental pra inisial dalam memahami konsep persamaan garis lurus terdapat 2 subjek yaitu subjek ADS dan subjek NS yang sudah sesuai dengan indikator level model mental, maka level model mental pra inisial tersebut valid.

2. Level Model Mental Inisial

Subjek AR tidak bisa menjawab soal tes dengan benar. Terlihat dari jawaban subjek AR untuk memasukkan dua titik ke rumus ia hanya menuliskan apa yang diketahui. Berikut jawaban subjek AR:
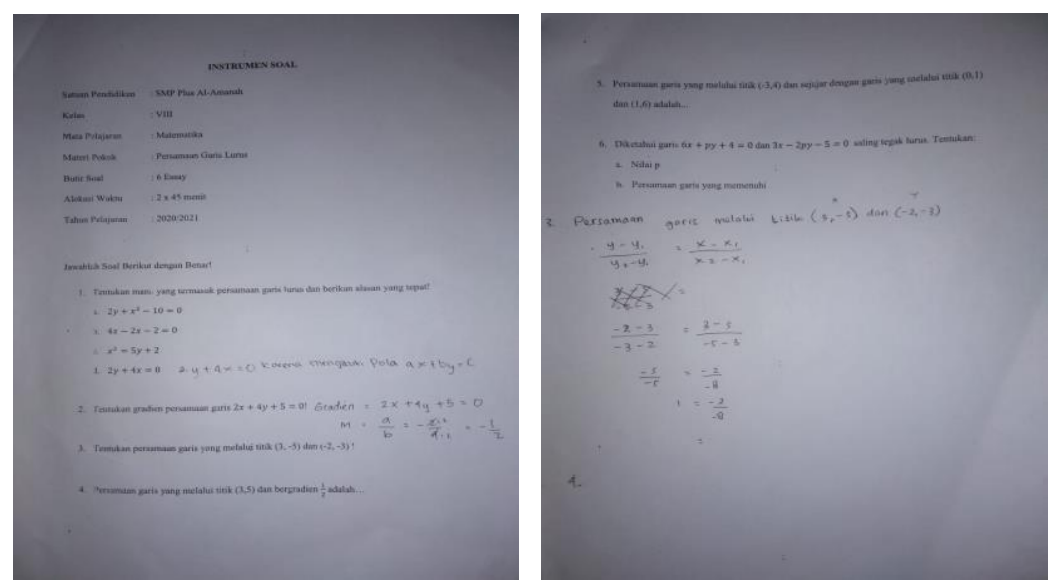
Gambar 3. Model Mental Inisial Subjek AR

Berdasarkan jawaban di atas menunjukkan bahwa jawaban dari subjek AR untuk nomor 1 dan 2 benar, terlihat bahwa sudah memahami persamaan garis lurus namun belum sempurna ketika memasukkan rumus persamaan garis lurus ketika mengerjakan soal. Terlihat juga pada gambar di atas bahwa subjek AR lebih fokus pada hal-hal yang diketahui dari soal tanpa penyelesaian yang benar. Berikut hasil cuplikan wawancara dengan subjek AR:
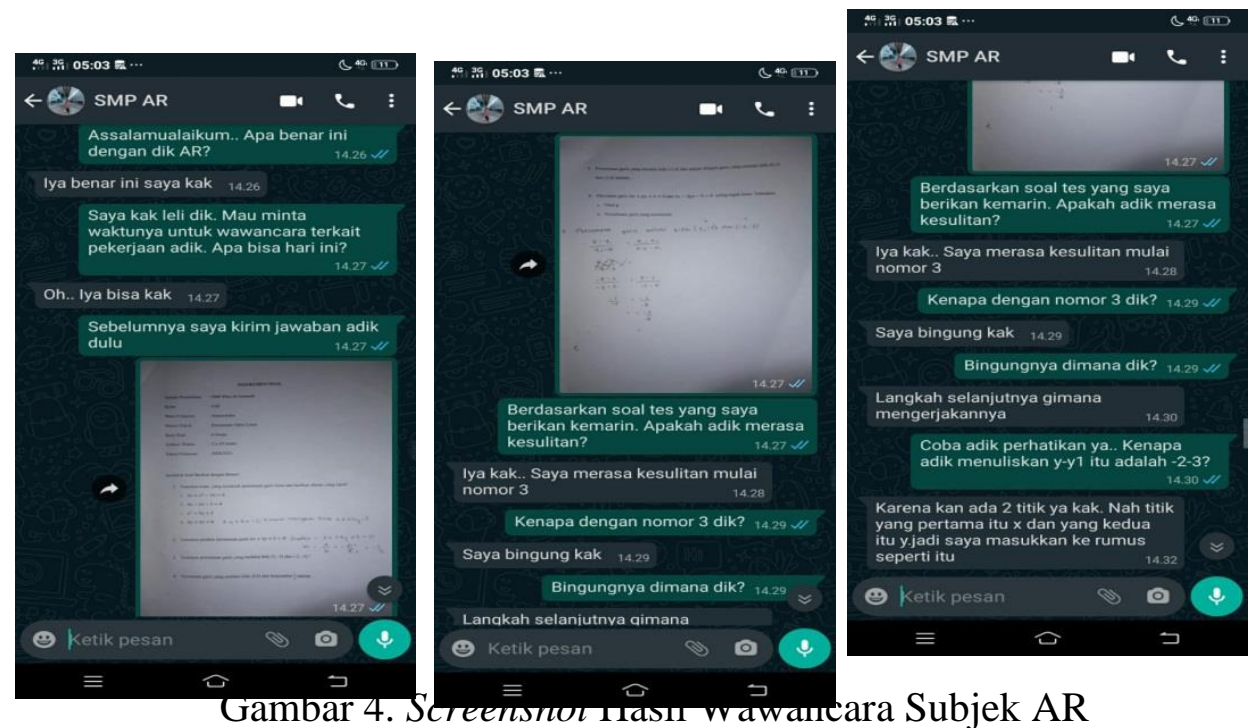

Berdasarkan hasil jawaban dan wawancara di atas, dapat disimpulkan bahwa subjek AR termasuk dari siswa yang sudah memahami konsep persamaan garis lurus sehingga subjek AR masuk dalam level model mental inisial.

Selain subjek AR juga terdapat subjek SM yang memiliki kesalahan yang sama. Sehingga level model mental inisial dalam memahami konsep persamaan garis lurus terdapat 2 subjek yaitu subjek AR dan subjek SM yang sudah sesuai dengan indikator level model mental, maka level model mental inisial tersebut valid.

3. Level Model Mental Transisi I

Subjek EAP tidak bisa menjawab soal tes dengan benar. Jawaban subjek EAP sebenarnya sudah hampir benar dalam menggunakan konsep persamaan garis lurus, namun belum benar dalam penyelesaiannya. Hal tersebut terlihat dari gambar berikut ini:
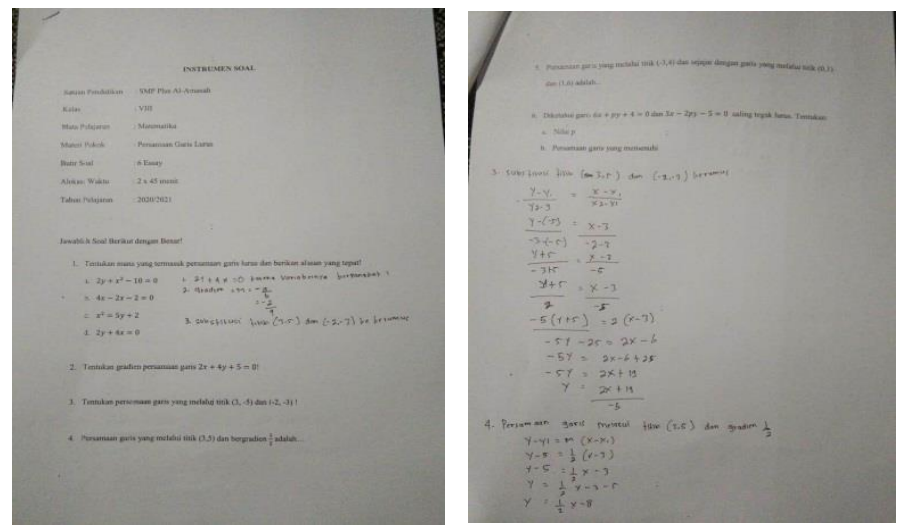


\section{Gambar 5. Model Mental Transisi I Subjek EAP}

Berdasarkan jawaban di atas menunjukkan bahwa subjek EAP salah dalam penyelesaian soal, seharusnya tandanya menjadi positif 5 bukan negatif. Hal ini terlihat dari cuplikan hasil wawancara berikut ini:
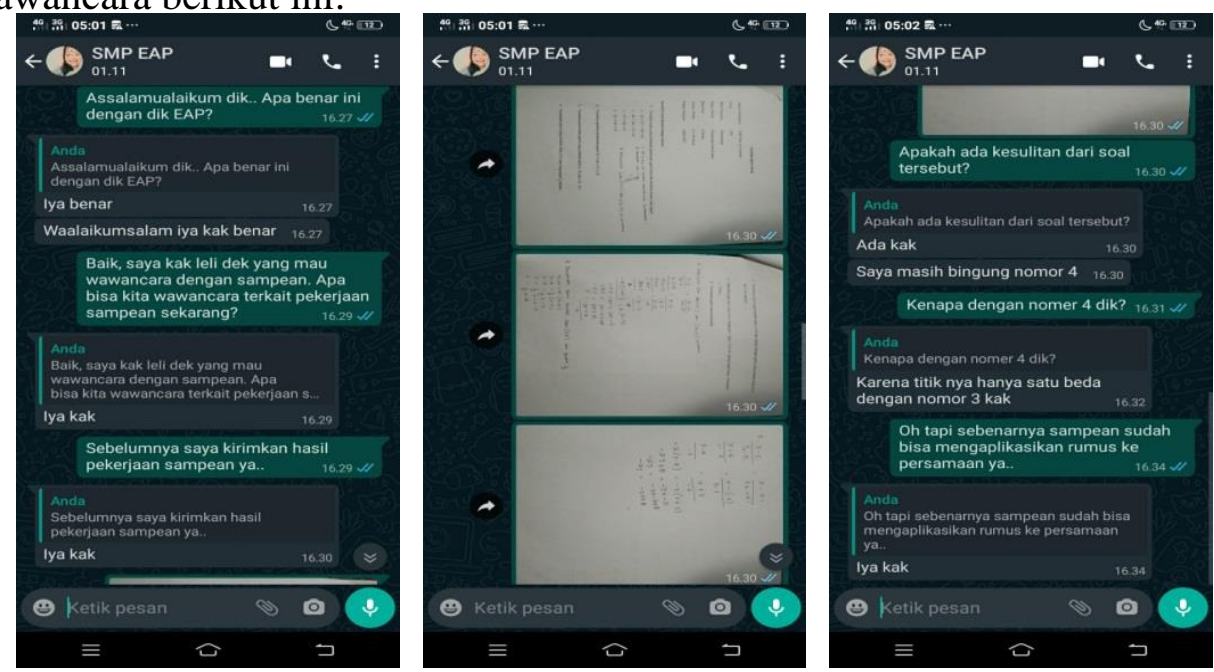

Gambar 6. Screenshot Hasil Wawancara Subjek EAP

Berdasarkan hasil jawaban dan wawancara dapat disimpulkan bahwa subjek EAP sebenarnya sudah memahami dan dapat mengerjakan soal terkait persamaan garis lurus. Hanya saja subjek EAP belum dapat konsisten benar dalam proses penyelesaiannya. Sehingga subjek EAP termasuk dalam level model mental Transisi I.

Selain subjek EAP juga terdapat subjek LR yang memiliki kesalahan yang sama. Sehingga level model mental transisi I dalam memahami konsep persamaan garis lurus terdapat 2 subjek yaitu subjek EAP dan subjek LR yang sudah sesuai dengan indikator level model mental, maka level model mental transisi I tersebut valid.

4. Model Mental Sintesis

Subjek ANF tidak bisa menjawab soal tes dengan benar. Jawaban subjek ANF nomo 1,2,3, dan 4 sudah benar semua. Untuk jawaban nomor 5 juga menunjukkan bahwa ia sudah bisa memahami konsep persamaan garis lurus dengan baik. Namun masih salah dalam proses pengerjaannya. Hal ini dapat dilihat dari gambar berikut ini:
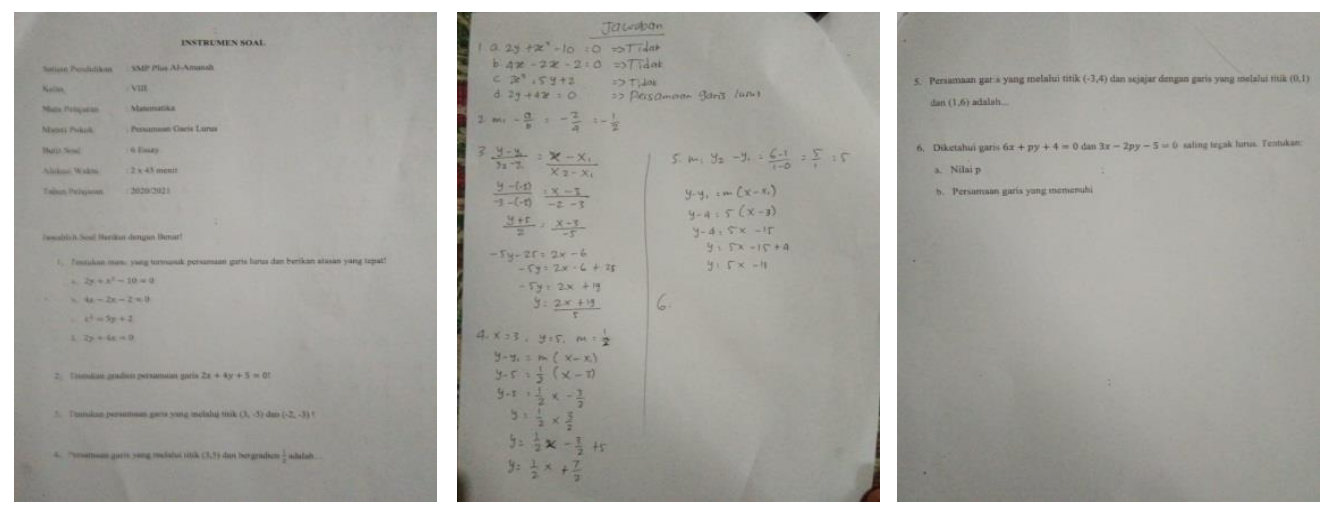


\section{Gambar 7. Model Mental Sintesis Subjek ANF}

Berdasarkan jawaban di atas, subjek ANF sudah memahami konsep dan dapat mengerjakan soal terkait persamaan garis lurus. Tetapi dalam proses pengerjaan, subjek ANF salah dalam menuliskan tanda yang seharusnya x1 itu bernilai positif (+3) bukan negatif (-3). Sehingga hasil jawaban belum tepat. Hal ini terlihat dari cuplikan hasil wawancara berikut ini:
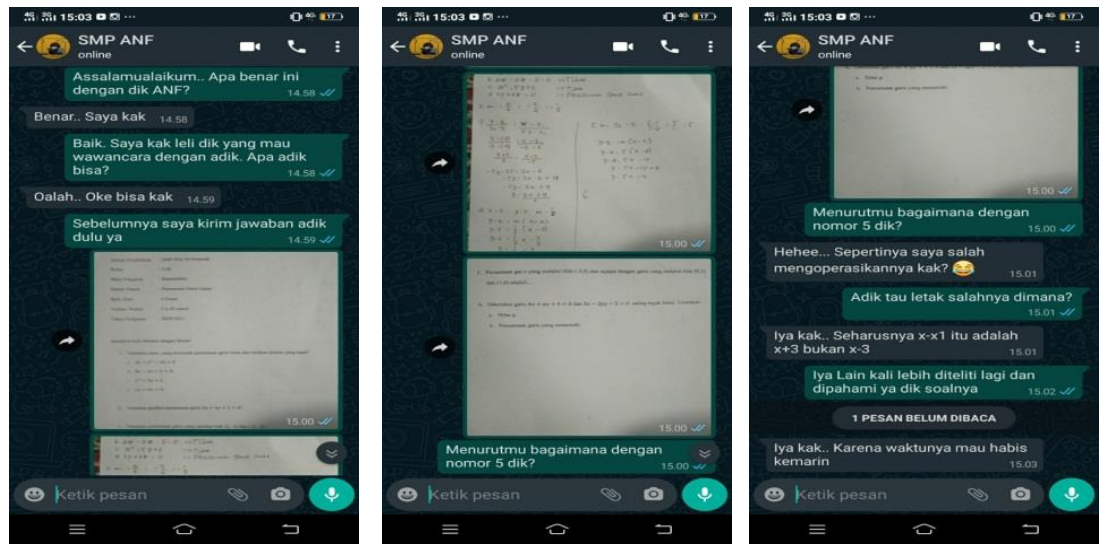

Gambar 8. Screenshot Hasil Wawancara Subjek ANF

Berdasarkan jawaban dan wawancara di atas, dapat disimpulkan bahwa subjek ANF sudah mulai memahami konsep persamaan garis lurus. Tetapi hasil yang diperoleh masih belum tepat, sehingga subjek ANF masuk dalam level model mental sintesis.

Selain subjek ANF juga terdapat subjek NDA yang memiliki kesalahan yang sama. Sehingga level model mental sintesis dalam memahami konsep persamaan garis lurus terdapat 2 subjek yaitu subjek ANF dan subjek NDA yang sudah sesuai dengan indikator level model mental, maka level model mental sintesis tersebut valid.

\section{Model Mental Transisi II}

Subjek AS tidak bisa menjawab soal tes dengan benar. Jawaban subjek AS pada nomor 5 sudah benar, namun saat memasuki soal nomor 6 ia salah. Hal ini terlihat dari gambar berikut:
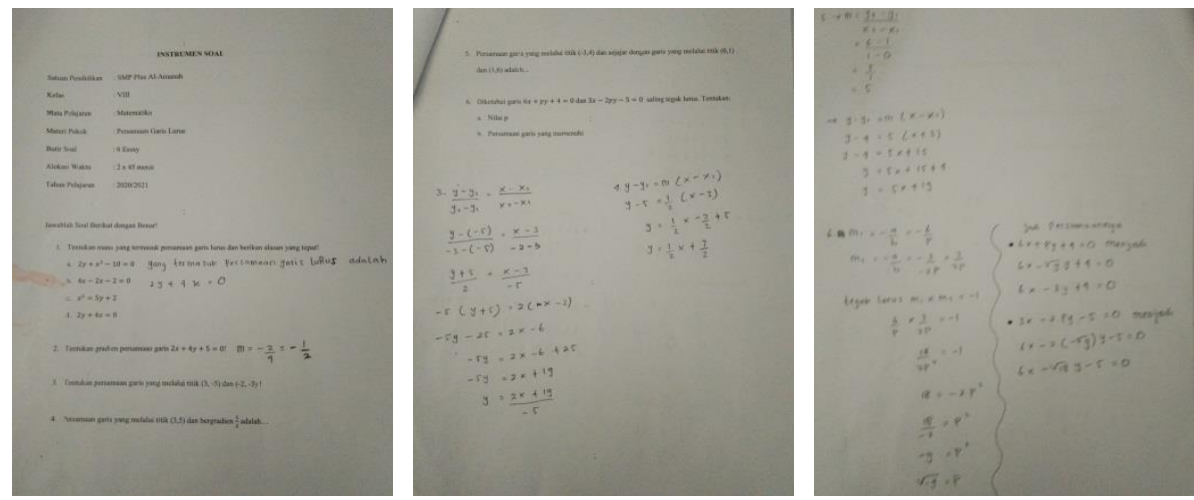


\section{Gambar 9. Model Mental Transisi II Subjek AS}

Berdasarkan jawaban di atas, menunjukkan bahwa subjek AS mampu memahami soal yang berkaitan dengan konsep persamaan garis lurus, karena ia dapat mengerjakan soal-soal pada nomor sebelumnya dengan baik. Hal ini terlihat dari cuplikan hasil wawancara berikut:
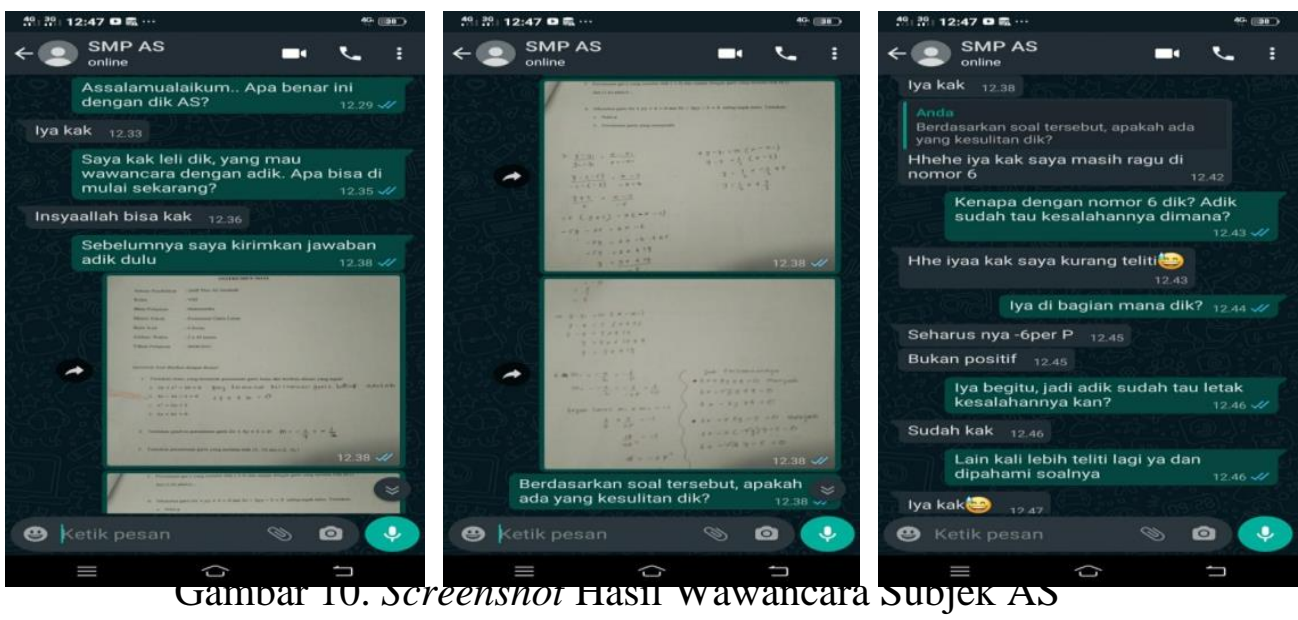

Berdasarkan jawaban dan wawancara di atas, dapat disimpulkan bahwa subjek AS sudah mampu memahami materi soal persamaan garis lurus, namun kurang konsisten ketika proses pengerjaannya. Sehingga subjek AS masuk dalam level model mental transisi II.

Selain subjek AS juga terdapat subjek NBN yang memiliki kesalahan yang sama. Sehingga level model mental transisi II dalam memahami konsep persamaan garis lurus terdapat 2 subjek yaitu subjek AS dan subjek NBN yang sudah sesuai dengan indikator level model mental, maka level model mental transisi II tersebut valid.

6. Level Model Mental Formal

Subjek CK sudah bisa memahami dengan baik dan benar serta konsisten dalam pengerjaan soal tes yang berkaitan dengan konsep persamaan garis lurus. Hal tersebut terlihat dari gambar berikut:
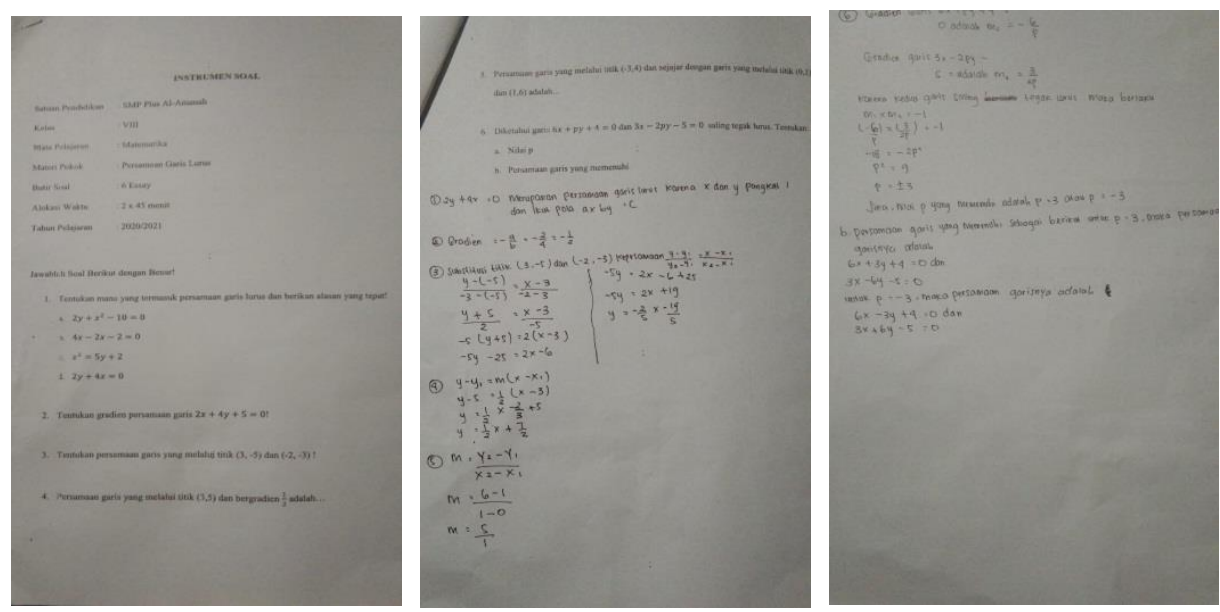


\section{Gambar 11. Model Mental Formal Subjek CK}

Berdasarkan jawaban di atas, terlihat bahwa subjek CK sudah bisa memahami dan mengerjakan semua soal tes berdasarkan konsep persamaan garis lurus. Hal tersebut dapat dilihat dari cuplikan hasil wawancara berikut ini:
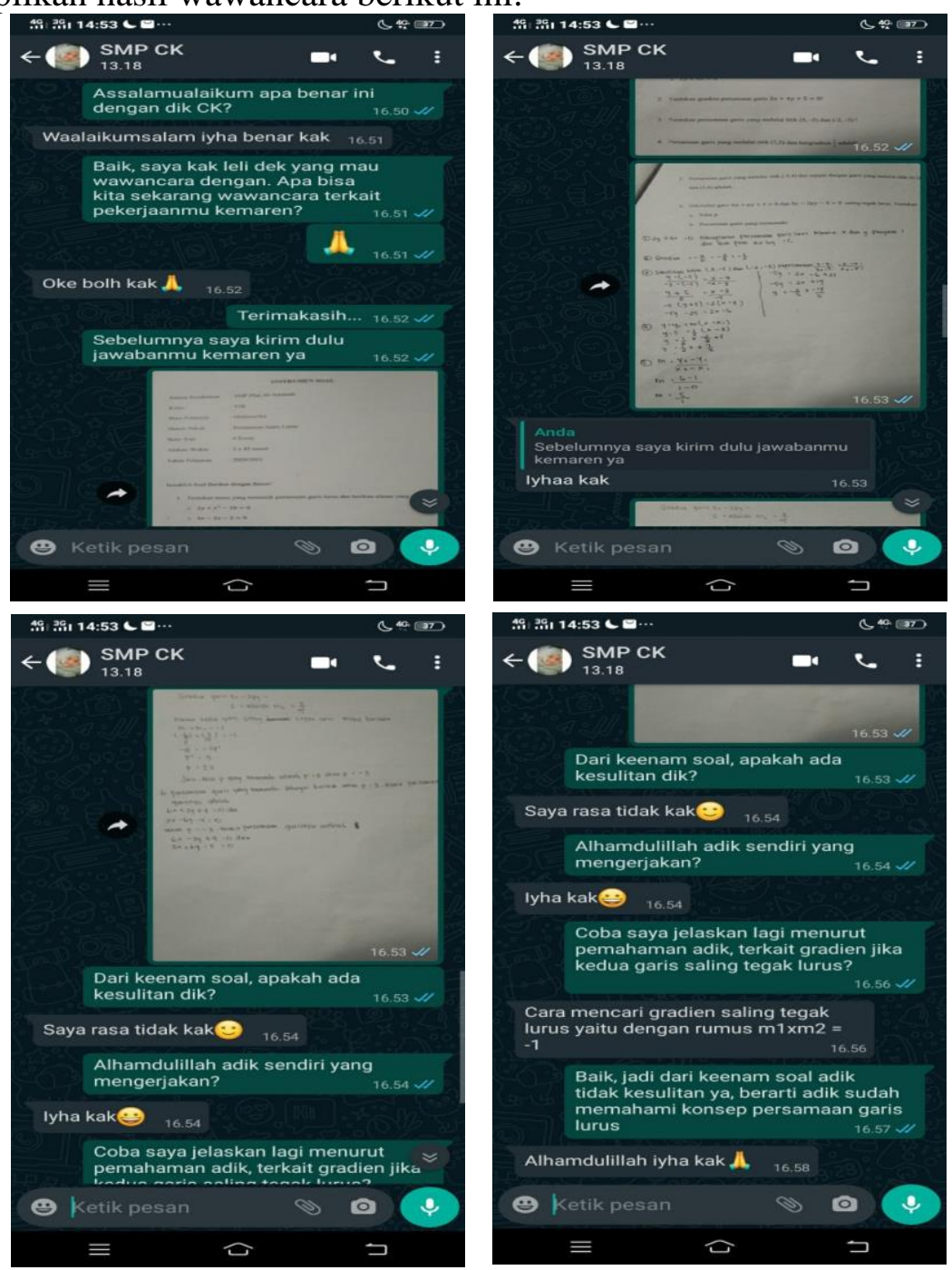

Gambar 12. Screenshot Hasil Wawancara Subjek CK

Berdasarkan jawaban dan wawancara di atas, dapat disimpulkan bahwa subjek CK bisa mengerjakan serta menjelaskan semua soal tes terkait konsep persamaan garis lurus. Sehingga subjek CK masuk dalam level model mental formal.

Selain subjek CK juga terdapat subjek DCP yang memiliki kesalahan yang sama. Sehingga level model mental formal dalam memahami konsep persamaan garis lurus terdapat 2 subjek yaitu subjek CK dan subjek DCP yang sudah sesuai dengan indikator level model mental, maka level model mental formal tersebut valid.

\section{Diskusi}

Berdasarkan hasil penelitian yang dilakukan oleh Utami (2018) menunjukkan bahwa ada enam level model mental siswa dalam memahami konsep bilangan bulat yaitu: model 
mental pra inisial, model mental inisial, model mental transisi 1, model mental sintesis, model mental transisi 2, dan yang terakhir model mental formal. Utami (2018) mengembangkan enam level model mental tersebut berdasarkan pelevelan model mental Bofferding (2014) yang membagi lima level model mental siswa dalam memahami konsep bilangan bulat. Pada penelitian ini, peneliti melakukan penelitian dengan berpedoman pada level model mental siswa dalam memahami konsep soal cerita Sistem Persamaan Linear Dua Variabel (SPLDV) yang telah dideskripsikan oleh $\underline{\text { Ulfah }(2020)}$ dengan enam level model mental yang telah dijabarkan oleh Utami (2018).

Penelitian terdahulu mengambil materi pemahaman konsep bilangan bulat dan pemahaman konsep soal cerita Sistem Persamaan Linear Dua Variabel (SPLDV) sedangkan materi dalam penelitian ini adalah pemahaman konsep persamaan garis lurus. Berikut penjabaran level model mental dalam memahami konsep persamaan garis lurus berikut ini:

Model mental pra inisial ditujukan kepada siswa yang sama sekali tidak memahami materi yang berkaitan dengan konsep persamaan garis lurus. Pada saat peneliti melakukan penelitian, peneliti menemukan 8 siswa masuk dalam level ini. Sebab kedelapan siswa tersebut sama sekali tidak bisa mengerjakan satu soal pun pada soal tes yang telah diberikan. Peneliti juga mengamati hasil wawancara kepada salah satu perwakilan dari keduanya bahwa subjek PI mengiyakan ketidakmampuannya dalam menjawab soal yang telah diberikan. Oleh karena itu, dari kesulitan yang mereka alami inilah peneliti mengkategorikan dalam level pra inisial. Sejalan dengan Utami (2019) yang menyatakan bahwa model mental pra inisial dalam memahami konsep fungsi dapat dilihat ketika mahasiswa belum memahami konsep relasi dengan baik dan belum mampu menyatakan bahwa suatu relasi bukan merupakan suatu fungsi.

Model mental inisial diberikan kepada siswa yang sudah mampu memahami rumus persamaan garis yang nantinya sedikit menyinggung pemecahan masalah pada konsep persamaan garis lurus. Saat peneliti melakukan penelitian, ditemukan 16 siswa masuk dalam level ini. Dari 16 siswa ini hampir semuanya hanya benar dalam mengerjakan dua soal yaitu soal nomor 1 dan nomor 2 dari 6 butir soal tes yang telah diberikan. Saat diamati dengan perwakilan salah satu dari siswa tersebut, ternyata masing-masing dari mereka hanya memahami rumus yang berkaitan dengan konsep persamaan garis lurus yang masih dalam kategori mudah. Ketika dihadapkan dengan soal yang lebih berkembang, ia akan merasa kesulitan dan tidak dapat menyelesaikan. Sesuai dengan pernyataan Cooney (Kumalasari, 2013) bahwa kesulitan siswa dalam mempelajari matematika dikategorikan dalam tiga jenis diantaranya : a) kesulitan dalam mempelajari konsep, b) kesulitan dalam mempelajari prinsip, c) kesulitan dalam menyelesaikan masalah verbal.

Model mental transisi I diberikan kepada siswa yang sudah mampu memahami rumus dan persoalan pemecahan masalah yang berkaitan dengan konsep persamaan garis lurus, akan tetapi mereka masih belum bisa konsisten dalam proses pengeraannya. Pada saat peneliti melakukan penelitian, ditemukan 21 siswa masuk dalam level ini. Siswa tersebut hampir semuanya hanya benar dalam pengerjaan tiga soal saja yaitu nomor $(1,2$, dan 3$)$ dari 6 soal tes yang diberikan. Setelah diamati dengan perwakilan dari salah satu dari mereka, ternyata masing-masing dari mereka sebenarnya sudah memahami materi yang berkaitan dengan konsep persamaan garis lurus akan tetapi mereka masih belum bisa konsisten benar dalam pengerjannya. Bagi mereka yang masuk dalam level transisi 1 ini kekonsistensian memang dirasa sulit dan harus terus dilatih, meskipun yang mereka pahami baru sebatas rumus yang nantinya berkaitan dengan konsep persamaan garis lurus. Tidak hanya level ini, menurut Maya (dalam Rahmawati, dkk., 2019) menyatakan bahwa konsisten belajar setiap hari untuk objekobjek pelajaran yang memang dianggap penting adalah cara yang ideal untuk membuat proses belajar menjadi lebih mendalam. 
Model mental sintesis diberikan kepada siswa yang sudah bisa memahami rumus yang berkaitan dengan konsep persamaan garis lurus dengan kategori soal yang lebih sulit. Memulianya mereka dalam pengerjaan atau pemahaman tentang materi persamaan garis lurus ini sejalan dengan pendapat dari Krathworl dalam Lewy et al (2009: 16) bahwa siswa dapat menganalisis informasi yang masuk dan membagi-bagi atau menstrukturkan informasi ke dalam bagian yang lebih kecil untuk mengenali pola atau hubungannya. Berdasarkan pendapat tersebut, dapat diketahui dalam pengerjaan rumus-rumus yang mengandung pemecahan masalah persamaan garis lurus akan berkaitan dengan konsep persamaan garis lurus. Saat peneliti melakukan penelitian ditemukan 35 siswa masuk dalam level ini. Hampir semuanya hanya benar dalam pengerjaan empat soal saja dari 6 butir soal tes yang diberikan, yakni nomor $1,2,3$, dan 4 . Setelah diamati dengan perwakilan dari salah satu subjek yang dipilih, ternyata masing-maisng dari mereka memang sudah memahami dengan baik dan benar tentang materi yang berkaitan dengan konsep persamaan garis lurus.

Model mental transisi II diberikan kepada siswa yang sudah bisa memahami rumus persamaan garis lurus hingga pemecahan masalah yang berkaitan dengan konsep persamaan garis lurus. Akan tetapi mereka belum konsisten dalam memahami dan mengerjakan soal dengan baik dan benar. Saat peneliti melakukan penelitian, ditemukan 22 siswa yang masuk dalam level ini. Dua puluh dua siswa ini hampir semuanya benar dalam pengerjaan lima soal dari 6 butir soal yang diberikan, yakni nomor 1, 2, 3, 4, dan 5. Setelah diamati dengan perwakilan dari salah satu subjek yang dipilih, ternyata masing-masing dari mereka sebenarnya masih ingat materi persamaan garis lurus, namun masih ada ketidakkonsistenan dalam pengerjaannya. Oleh karena itu perlu adanya kedisiplinan dalam latihan soal-soal dan ketelitian agar siswa merasa lebih mudah dalam mengerjakan berbagai soal matematika. Sejalan dengan Ma'sumah (2015: 4) yang menyatakan bahwa disiplin belajar memliki peran yang penting yakni akan membuat siswa memiliki kecakapan mengenai cara belajar yang baik sehingga memperoleh prestasi belajar yang baik pula.

Model mental formal diberikan kepada siswa yang sudah dapat memahami rumus serta pemecahan masalah yang berkaitan dengan konsep persamaan garis lurus. Saat peneliti melakukan penelitian, peneliti menemukan 19 siswa masuk dalam level ini, siswa tersebut telah berhasil mengerjakan 6 butir soal yang diberikan dengan sempurna. Setelah peneliti amati bahwa salah satu subjek terpilih yang peneliti jadikan sebagai perwakilan, ternyata masingmasing dari mereka benar-benar telah konsisten dengan baik dan benar dalam mengerjakan soal-soal yang diberikan. Subjek yang berhasil masuk dalam level model mental ini dapat dikatakan sebagai subjek yang sempurna dalam pemahaman dan termasuk subjek yang dapat berpikir tingkat tinggi karena telah mampu memecahkan masalah (soal tes uraian) dengan sempurna. Sesuai dengan Dewanto (Amalia, 2016: 119) yang menyatakan bahwa kemampuan berpikir tingkat tinggi adalah salah satu kapasitas di atas informasi yang diberikan, dengan sikap yang kritis untuk mengevaluasi, mempunyai kesadaran (awareness) metakognitif dan memiliki kemampuan pemecahan masalah

\section{Simpulan}

Berdasarkan hasil penelitian yang telah peneliti lakukan maka dapat ditarik kesimpulan bahwa peneliti deskripsikan terkait beberapa level model mental dalam memahami konsep persamaan garis lurus, yakni: Pertama, model mental pra inisial dimana pada level mental ini siswa dapat dilihat dari informasi yang dimiliki yang tersimpan dalam memori jangka panjangnya sebelum mereka dihadapkan pada sebuah konsep tertentu. Siswa sama sekali tidak mengetahui rumus yang berkaitan dengan konsep persamaan garis lurus. Kedua, model mental yang kedua adalah model mental inisial, dimana menunjukkan bahwa siswa sudah mampu memahami rumus yang berkaitan dengan persamaan garis lurus. Siswa sudah mencapai tingkat 
kepahamannya. Sehingga beberapa persoalan yang sedikit menyinggung kaitannya dengan persamaan garis lurus sudah dapat dipahami dan diselesaikan. Ketiga, model mental yang ketiga adalah model mental transisi 1, pada level ini menunjukkan bahwa siswa sudah mampu memahami rumus yang kaitannya dengan persoalan pemecahan masalah yang ada padakonsep persamaan garis lurus. Akan tetapi mereka tidak konsisten dalam pengerjaannya. Mereka masih sering salah dan belum tepat dalam pengerjaannya. Keempat, model mental yang keempat adalah model mental sintesis, pada level ini menunjukkan bahwa siswa sudah mampu memahami dengan baik dan konsisten benar dalam mengerjakan serta mulai memahami materi persamaan garis lurus. Kelima, Model mental yang kelima adalah model mental transisi 2, pada level ini menunjukkan bahwa siswa sudah memahami segala materi yang berkaitan dengan konsep persamaan garis lurus terutama langkah - langkah dalam mengerjakannya, namun siswa tidak konsisten dalam memahami dan mengerjakan soal. Beberapa persoalan mengenai persamaan garis lurus masih sering salah. Keenam, model mental formal, dimana pada level ini siswa dikatakan sempurna dalam pemahaman. Karena pada level model mental ini siswa sudah mampu memahami dengan baik dan benar serta konsisten dalam pengerjaan materi yang berkaitan dengan konsep persamaan garis lurus.

Hasil penelitian yang diperoleh terdapat 6 pasang subjek yang telah dipilih, yang mana mewakili masing - masing level model mental pada tingkat pemahaman konsep persamaan garis lurus dan memiliki hasil jawaban yang benar pada tes tulis serta sesuai dengan hasil data wawancara sehingga diperoleh data yang valid.

\section{Konflik Kepentingan}

Penulis menyatakan tidak ada konflik kepentingan

\section{Referensi}

Amalia, R. (2016). Kemampuan Berpikir Matematis Mahasiswa dalam Menyelesaikan Masalah Geometri. EDU-MAT: Jurnal Pendidikan Matematika, 4(2).

Bofferding, L. (2014). Negative integer understanding: Characterizing first graders' mental models. Journal for Research in Mathematics Education, 45(2), 194-245.

Hadiyanti, R. (2012). Keefektifan Pembelajaran Kooperatif Numbered Head Together Terhadap Kemampuan Pemahaman Konsep. Unnes Journal of Mathematics Education, 1(1).

Jansoon, N., Coll, R. K., \& Somsook, E. (2009). Understanding Mental Models of Dilution in Thai Students. International Journal of Environmental and Science Education, 4(2), 147-168.

Kumalasari. (2013). Kesulitan Belajar Matematika Siswa Ditinjau Dari Segi Kemampuan Koneksi Matematika. Seminar Nasional Matematika Dan Pendidikan Matematika Fmipa Uny Yogyakarta, 9 November 2013. Mp 8 - Mp 14.

Lehrer. (2009). Identifikasi Kesalahan-Kesalahan Yang Diperbuat Siswa Kelas Iii Smp Pada Setiap Aspekpenguasaan Bahan Pelajaran Matematika. Tesis FPS IKIP Malang. Tidak Diterbitkan 
Lewy, L., Zulkardi, Z., \& Aisyah, N. (2009). Pengembangan soal untuk mengukur kemampuan berpikir tingkat tinggi pokok bahasan barisan dan deret bilangan di kelas IX akselerasi SMP Xaverius Maria Palembang. Jurnal Pendidikan Matematika, 3(2), 14-28.

Ma'sumah. (2015). Pengaruh Disiplin Belajar Terhadap Prestasi Belajar Siswa Kelas IV Sekolah Dasar Negeri Sedaerah Binaan Ii Kecamatan Petanahan Kabupaten Kebumen, Skripsi, Semarang: Universitas Negeri Semarang.

Murizal, A. (2012). Pemahaman konsep matematis dan model pembelajaran quantum teaching. Jurnal pendidikan matematika, 1(1).

Park, E. J., \& Light, G. (2009). Identifying atomic structure as a threshold concept: Student mental models and troublesomeness. International journal of science education, 31(2), 233-258.

Rachmawati, N. S., Junarti, J., \& Utami, A. D. (2019). Pelevelan Model Mental Siswa Dalam Memahami Penggunaan Konsep Teorema Phytagoras pada Siswa SMP. Journal of Mathematics Education and Science, 2(2), 97-106.

Retnawati, H. (2017). Kesalahan Siswa SMP dalam Menyelesaikan Soal Persaman Garis Lurus. Pros. Semin. Nas. Mat. dan Pendidik. Mat., 9.

Sange, P. M. (2004). " The Fifth Discipline: The Art and Practice of the Learning Organization", by Peter M. Senge. Human Resource Management, 29(3), 343.

Sholekah. (2017). Analisis kesulitan siswa dalam menyelesaikan soal matematika ditinjau dari koneksi matematis materi limit fungsi. WACANA AKADEMIKA: Majalah Ilmiah Kependidikan, 1(2).

Tanjungsari, R. D., \& Soedjoko, E. (2012). Diagnosis kesulitan belajar matematika SMP pada materi persamaan garis lurus. Unnes Journal of Mathematics Education, 1(1).

Ulfah, M. (2020). Pelevelan model mental siswa dalam memahami konsep soal cerita SPLDV. Jurnal Pendidikan Edutama.

Utami, A. D. (2018). Six Level Of Primary School Student's Mental Model In Comprehending The Concept Of Integer: A Case In Indonesia Context. International Jurnal of Instruction, 11(4), 29-44.

Utami, A. D. (2019). Students' Pre-Initial Mental Model: The Case of Indonesian First-Year of College Students. International Journal of Instruction, 12(1), 1173-1188.

Vosniadou, S., \& Brewer, W. F. (1992). Mental models of the earth: A study of conceptual change in childhood. Cognitive psychology, 24(4), 535-585. 
